Review Article

\title{
Smallholder Farmers Agricultural Commercialization in Ethiopia: A Review
}

\author{
Addisu Getahun \\ Ethiopian Institute of Agricultural Research (EIAR), Holetta Agricultural Research Center, Addis Ababa, Ethiopia \\ Email address: \\ addisgeta127@gmail.com \\ To cite this article: \\ Addisu Getahun. Smallholder Farmers Agricultural Commercialization in Ethiopia: A Review. Agriculture, Forestry and Fisheries. \\ Vol. 9, No. 3, 2020, pp. 67-74. doi: 10.11648/j.aff.20200903.14
}

Received: March 27, 2019; Accepted: February 25, 2020; Published: June 4, 2020

\begin{abstract}
The agricultural production sector is a backbone of the Ethiopian economy. In Ethiopia 95\% of the total area is cultivated by smallholder farmers and contribute $90 \%$ of the total agricultural output. As reviewed from different literatures household demographic characteristics, household resource endowments, social, cultural, infrastructural, institutional and economic factors influence the level of smallholders' commercialization. In this regard, to enhance smallholder's commercialization generating improved high yielding varieties and adoption of these newly released technologies through agricultural research is crucial, public investments in infrastructural development and government policies that improve institutional arrangements are essential. Development agents at rural peasant association have to be properly advice farmers on agricultural production and marketing, farmers' cooperative and farmers' organization are required to enable smallholder farmers collectively accessing agricultural inputs, credit, information and marketing of their produce. In general, based on the review of smallholders' commercialization rigorous efforts of all stakeholders including governments, research institutions, universities, farmers, NGOs, and development practitioners are essential to eliminate the existing bottlenecks to improve the livelihood of smallholder farmers.
\end{abstract}

Keywords: Smallholders, Commercialization, Determinants and Impacts

\section{Introduction}

The agricultural sector is a mainstay of the Ethiopian economy. In Ethiopia $95 \%$ of the total area is cultivated by smallholder farmers and contribute $90 \%$ of the total agricultural output indicating the dominant contribution of smallholder farmers to the overall agricultural growth in the country and that the entire movement of the agriculture sector depends on what is happening in smallholder sub-sector [1]. Commercialization of the smallholder farmers have been viewed by the government as the major source of agricultural growth in Ethiopia. The Ethiopian government, in its two consecutives five-year Growth and Transformation Plans (GTP-I and GTP-II), given much emphasis on agricultural commercialization, among which the second pillar intends to achieve growth and thereby improve people's livelihoods and reduce poverty through intensifying the agricultural productions [2].
In the agriculture sector, commercialization refers to the progressive shift from household production for home consumption to production for sale in the market to generate income [3]. It entails agricultural production decision destined for market based on market signals and produce offered for sale and use of purchased inputs [4]. Market-oriented production has achieved welfare gain through specialization, comparative advantage, economies of scale, regular interaction and exchange of ideas to agricultural production [5]. Commercializing smallholder agriculture is an indispensable pathway towards economic growth and development for most developing countries relying on the agricultural sector [6]. The welfare gains from market-oriented production arise from specialization that builds on and creates comparative advantages, potential for large-scale production, and from dynamic technological, organizational and institutional change effects that arise through the flow of ideas due to 
exchange-based interactions among smallholder farmers and market participants [7].

Commercialization demands agricultural production decision destined for market based on market signals and produce offered for sale and use of purchased inputs. Commercialization has a linking power between input and output sides of a market; demand for modern technologies promotes the input side of production and facilitates the development and advancement of technological innovations. In turn, the use of modern technologies can result in higher productivity and production entering markets. However, relatively there is a literature analyzing the extent of commercialization for crop production, the commercialization process in the livestock subsector have received little attention out of the agricultural sector [4]. Thus, this review has based primarily on the process, determinants and driving factors of smallholder farmers commercialization in Ethiopia. The objectives of this review are to appraise the smallholder farmers' agricultural commercialization in Ethiopia.

\section{Notions on Smallholders and Agricultural Commercialization}

\subsection{Smallholder Farmers}

Smallholder has several definitions by different scholars despite this fact, in more literature there exist some common explanation about smallholders. Smallholder farmers are defined as the basis of land and livestock holdings, cultivate less than two hectares of land and own only few herds of livestock [8]. Smallholders are the areas with high population densities, farmers usually cultivate less than one hectare of land, which may increase up to ten hectare or more in semi-sparsely populated arid areas, in combination up to ten animals [9].

The majority of farmers in Ethiopia are subsistence smallholders, with little separability between production and consumption decisions of the household [10]. Smallholders in Ethiopia are known for their resource constraints such as capital, inputs and technology, their heavy dependence on household labor, their subsistence-orientation, and their exposure to risk such as reduced yields, crop failure and low market prices of the produce [11].

\subsection{Agricultural Commercialization}

Agricultural Commercialization is defined as the progressive shift from household production for auto-consumption to production for sale in the market. This shift entails that production and input use decisions are based on profit maximization, reinforcing vertical linkages between the input and output markets [3]. Agricultural commercialization is a process involving transformation of agriculture to market-oriented production which tends to impact income, consumption and nutritional setup of the farm households. Agricultural commercialization is more than producing surplus output to the market and thus includes household's decision behavior on product choice and input use based on the principle of profit maximization. Agricultural commercialization normally takes three important stages. In subsistence level, farmer's main goal is the provision of his/her own food by using household and non-tradable inputs. In the semi-commercial level, the farmers' objective changes to generating a surplus which could be traded in the market. $\mathrm{He} / \mathrm{she}$ uses both tradable and non-tradable inputs. In a fully commercialized agricultural level, the farmers' objective was maximization of the profit and the production inputs are obtained from the markets [6]. However, there is also the prevalence of commercialization in subsistence agriculture where farm households supply certain proportion of their output to the market for sale [12].

\subsection{Crop Production in Ethiopia}

According to Ethiopian central statistical agency the production of major crops information indicates the cropped land area and production of both annual and perennial crops. The total land area of about 12,486,270 hectares are covered by grain crops (i.e. cereals, pulses and oilseeds), from this a total volume of about $266,828,807$ quintals are obtained [13].

Cereals: include tef, maize, sorghum and wheat are grown in all regions. Out of the total grain crop area, $80 \%(9,974,316$ ha) was under cereals and contributed $87 \%$ (about $231,287,970 \mathrm{qt}$ ) of the grain production. Pulses: include faba beans, haricot beans (white and red), and chick peas covered $13 \%(1,652,844 \mathrm{ha})$ of the grain crop area and $10 \%$ (about $27,692,743 \mathrm{qt}$ ) of the grain production. Oil seeds: include nug, sesame and linseed constitute 7\% (about 859,110 ha) of the grain crop area and 3\% (about 7,848,093 qt) of the production. Vegetables: include red peppers and Ethiopian cabbage, took up about $1.4 \%$ of the area under all crops at national level and contribute $2.2 \%$ of the total crop production. Root crops: like onion and garlic are indispensable to improve the taste and scent of the food. Others like potatoes, sweet potatoes and taro are major root crop constitute $1.5 \%$ of the total production [13].

Fruits: includes bananas, mangoes, avocados papayas, and oranges cover about 92,362 hectares of land and more than $6,797,428$ quintals of fruits was produced in the country. Stimulant crops: such as chat and coffee shared $1.8 \%$ and $4.7 \%$ of the area under all crops in the country and 2,026,966 and $4,145,964$ quintals of produce was obtained in the same agricultural year respectively. Sugar Cane: It is grown in small areas in some parts of the country. About 29,679 ha of land were under sugar cane in the country, yielding an estimated total of $13,769,813$ quintals. Enset: is mostly grown in south-western part of the country and covers considerable land area. The number of enset trees harvested, in the year, from all over the country is estimated to be $112,522,152$. Thus, amicho, kocho, and bula are 23,821,849 qt, 28,329,103 qt and 950,414 quintals, respectively [13]. 


\section{Agricultural Commercialization Scenarios}

\subsection{Processes of Smallholder Farmers Agricultural Commercialization}

Smallholders commercialization is part of an agricultural transformation process in which individual farmers shift from subsistence-oriented production towards more specialized production targeting markets both for their input procurement and output supply. There is an ongoing debate about targeting the process of smallholders' commercialization. One issue of debate is whether smallholder commercialization should aim at increasing the productivity and marketed surplus of staple food crops or focus on a newly introduced high value crops. The second issue was whether to produce these commodities for domestic or export markets [14]. The review on such choices are indicated under the following subsections.

\subsubsection{Staple or High-value Cash Commodities}

The argument on which commodities to target in the process of smallholders' commercialization emanates from the agro-ecological circumstances, technical knowledge of smallholders, and their risk bearing capacity and attitude towards risk. Since staple food crops have been produced for a longer period under the subsistence system, it is believed that smallholders have the technical knowledge and experience in the production of these commodities. On the other hand, different modes of production targeting high-value non-traditional commodities could help farm households to generate more income per unit of resources used on the farm but at a higher production and market risk on the produce [14]. For many farmers, the transition from subsistence to commercial staple crop production is far more significant than a complete shift to specialized high-value commodities due to the fear of higher production and market risk in the commodities at production [15].

The production of marketable surplus of staple food over what is needed for own consumption is initially the most common form of commercialization in a peasant agriculture. Through time, as the level of smallholders' commercial orientation increases, one observes mixed staple and cash crop production systems giving a way to specialized production units for the production of high-value crop [12]. For some farmers, commercialization can offer the possibility of diversification into non-staples, but not a total specialization [15]. Thus, agricultural commercialization is believed to put increased emphasis on specialization, it is not confined to the production of high-value commodities only. Increasing commercialization trends lead to both a seasonal diversification out of monoculture systems is important for sustainability of production.

\subsubsection{Domestic or Export Market}

The choice of either domestic or export markets in the process of smallholder commercialization is basically linked to the nature of the targeted commodities. For countries with large population size, domestic markets could also be a major market target due to higher domestic demand for both staples and high-value commodities [14]. In targeting the export market for the process of smallholder commercialization, the issue of product quality, sanitary and phytosanitary standards, timely and regular supply, and volume need to be given emphasis in enabling the small-scale farmers to be part of the game. Apart from the intercontinental export markets for high-value cash crops, there is a considerable potential demand for staple commodities in the domestic and intra-regional food markets of developing countries.

\subsection{Methods of Measuring Level of Smallholders Commercialization}

The relevance of measuring the level of smallholder commercialization arises from the interest to make comparisons of households according to their degree of commercialization. In addition, it also helps to gauge to what extent a given farm household is commercialized in its overall production, marketing and consumption decisions, and to analyze the determinants of commercialization [14]. Different approaches are used to measure the level of agricultural commercialization.

Commercialization can be measured along a continuum from zero (total subsistence-oriented production) for home consumption to one ( $100 \%$ production is sold) to the market for generating incomes to the household. There are three types of commercialization index at household level: output and input side commercialization, commercialization of the rural economy, and integration of the households into the cash economy which is the value of goods and services acquired through cash transaction with respect to total income [16]. The first index measures proportion of agricultural output sold to the market and input acquired from market to the total value of agricultural production. In the second type, commercialization of the rural economy is defined as the ratio of the value of goods and services acquired through market transactions to total household income. Here, there is an assumption that some transactions may take place in-kind such as payments with food commodities for land use.

Thirdly, the degree of household integration to the cash economy is measured as the ratio of the value of goods and services acquired by cash transaction to the total household income. They are stated below with the following ratios:

$$
\begin{gathered}
\text { Commercialization of Agriculture (Output Side) }=\frac{\text { Value of Agricultural sales in market }}{\text { Agricultural Production Value }} \\
\text { Commercialization of Agriculture (Input Side) }=\frac{\text { Value of Inputs aquired from market }}{\text { Agricultural Production Value }}
\end{gathered}
$$




$$
\begin{gathered}
\text { Commercialization of rural economy }=\frac{\begin{array}{c}
\text { Value of goods and services aquired } \\
\text { through market transactions }
\end{array}}{\text { Total Income }} \\
\text { Degree of Integration into the cash economy }=\frac{\begin{array}{c}
\text { Value of goods and services aquired } \\
\text { by cash transactions }
\end{array}}{\text { Total Income }}
\end{gathered}
$$

Commercialization is also measured at household level as either in terms of gross sales measured as the ratio of percentage value of gross marketed output to total farm production [14]. In measuring household-specific level of commercialization, household commercialization index (HCI) is used, which is a ratio of the gross value of all crop sales per household per year to the gross value of all crop production. Mathematically it is expressed as:

$$
\mathrm{HCI}_{\mathrm{i}}=\frac{\text { Total Value of crop soldi }}{\text { Total Value of crop producedi }} \times 100
$$

Where: $\mathrm{HCI}_{\mathrm{i}}=$ commercialization index of $\mathrm{i}^{\text {th }}$ household having a value between zero up to one and total value of crop sold and produced indicates the value of crop sold and produce by $i^{\text {th }}$ farmer.

\subsection{Determinants of Smallholder Farmers Agricultural Commercialization}

Determinants of smallholder farmers' commercialization can be broadly categorized as external and internal factors. The external factors are beyond the smallholders' control like population growth, technological change and introduction of new commodities, development of new infrastructure and market institutions, development of the non-farm sector, rising opportunity cost of labor, trade and sectoral policies affect the market prices [6]. On the other hand, factors like smallholders' resource endowments including land and other natural capital, labor, physical capital, human capital are household specific and considered to be internal determinants [14]. Thus, factors hindering successful smallholder farmers' commercialization are stated bellow:

\subsubsection{Demographic Factors}

Household characteristics such as the family size, educational levels, farming experience and sex of the household head found to determine the household's decision to participate in commercial markets as well as the type of crops that households produce [17]. The larger family size lower marketed surplus than smaller family size, since at larger family size higher proportion of output consumed at home and the smaller proportion of produce was available for market [18].

\subsubsection{Economic Factors}

Economic resources have significant impact on the participation and degree of agricultural commercialization. Lack of assets may preclude many smallholder farmers from being able to produce a surplus necessary for participating in output markets as sellers. Size of land holding and total amount of household income (including non/off-farm income) were a significant determinant of level of smallholder commercialization. Similarly, the intensity of livelihood diversity and total volume of farm products appeared to significantly influence both market participation and level of commercialization [19]. Land is the most valuable asset in the rural household to affect the decision of the household to participate in output market [18].

\subsubsection{Agricultural Support Services}

Smallholder farmers have a potential, ability and willingness to commercialize their farming enterprises, but they are hampered by lack of access to market information, agricultural credit, adequate and timely agricultural advisory services and lack of access to input markets for high yielding varieties and inorganic fertilizer. Lack of agricultural support services is mainly a hindrance to agricultural commercialization for smallholder farmers [17].

\subsubsection{Transaction Costs and Institutional Factors}

Transaction costs and Institutional factors are a critical factor hindering the sustainable participation of smallholder farmers in commercialization, in the process of information searching, contract negotiating, and costs associated with transporting outputs to + the market. In many cases the buyers of agricultural produce such as agribusiness owners are generally large and they are able to take advantage of economies of scale and exert market power over small scale producers. Smallholder producers have low production capacities which entails that they are unable to rapidly change their production volumes in order to meet the market demands, and they are unable to keep up with cost reducing technological advances thus making them less competitive [17].

\subsubsection{Infrastructural Factors}

Increased in production capacity to participate in lucrative markets are rendered unsuccessful by the absence of infrastructure such as road networks, telephone and electricity. In cases in which groups of farmers are successful in becoming market oriented in terms of their production, the remoteness as well as the lack of road infrastructure prevents them from responding to higher market prices. Moreover, improved infrastructure reduces transaction costs thus facilitating smallholder farmers' access to high market prices [17]. Poor rural road networks, lack of appropriate transportation facilities and poor communication system are negatively correlated with marketed surplus because of the increased transaction costs the farmers unable to supply their produce to the market thus the amount of produce that going to the market left at home [20].

\subsubsection{Marketing Factors}

Absence of market for the produce (inability of the local 
market to absorb produced output, particularly for vegetables and fruits), fall in price and high input prices (improved seeds), were bottlenecks to crop commercialization as these factors have an impact on agricultural productivity. A reduction in price of crops occurs during the harvesting season as most of the farmers take their produce to the market during the same period this creates market surplus and reduce prices with eventual fall in household income. As a result, farmers discouraged to produce market-oriented commodities [21].

\subsubsection{Climate Change-induced Risks and Uncertainty}

Climate change affects smallholders in the form of weather-induced shocks such as, drought and floods that directly affect agricultural production and marketable surpluses. Shocks emanating from changes in seasons, crop pest and diseases, floods and droughts affect agricultural household production and hence participation in the market. Climate change influences not only the production and productivity of agriculture, but also the quality of produce supplied to markets. In addition, at the home of smallholder farmers where there is a lack of appropriate storage facilities produces are highly vulnerable for rotting, loss due to rodents, and infestation [19].

\section{Impacts of Commercialization and Methods to Enhance}

\subsection{Impact of Smallholder Farmers Agricultural Commercialization}

Smallholders' commercialization is assumed to lead towards more specialized production and systems based on comparative advantages in resource use. In turn, commercialized production leads to higher productivity through greater learning by doing, exposure to new ideas and better incentives in the form of higher income. Impacts of commercialization can be categorized into first, second and third orders. The first-order was mainly income and employment effects that are directly reflected in households' welfare. The second-order effects include health and nutrition aspects usually contingent on the level of income attained through the existing level of commercialization. The third-order or higher order effects are the macro-economic and environmental effects that go beyond household level [14]. Some impacts of smallholder farmers' commercialization are specified below:

\subsubsection{Smallholders Welfare Effect}

The shift from subsistence agriculture towards market orientation (commercialized) can significantly increase the income and welfare of smallholder farmers as well as contribute to economic growth and poverty alleviation [22]. Commercializing smallholder farmer is a means to bring the welfare benefits of market-based exchange economies and it is central to an inclusive development process.

\subsubsection{Employment of Rural Youth}

A new generation of young, energetic potential entrepreneurs is emerging towards creating income and employment in agriculture. To develop an industry, in part by facilitating interested smallholders' transition from subsistence farming, rural youth must be targeted as part of a long-term transition strategy. The next generation of agribusiness entrepreneurs will be created by today's youth learning to be commercially oriented farmers and service providers [23]. However, whether a smallholders' commercialization process creates more employment opportunities in rural area is subject to the nature of commodities produced, technologies used in the production process, and whether agricultural processing is involved in the scheme [16].

\subsubsection{Food Crop Productivity}

Commercialization may improve food crop productivity that it provides a source of cash that allows the household to overcome cash constraints on the purchase of fertilizer, improved seed and other inputs. Participation in high value crop improves the households' access to agricultural inputs, commercialized farmers may use some of that input for food crop production, and cash income from commercialized production patterns also facilitates the ability to purchase draft oxen and traction equipment that may promote food crop productivity [24].

\subsubsection{Macroeconomic Effects}

Smallholders farmers' commercialization in developing countries with larger population engage in the agricultural sector can generate more income, thus improves economic growth. Increased income in the agricultural sector raises demand for manufactured goods and services in other sectors of the economy and agricultural product also used as raw materials for industries, thus this stimulate further economic growth. Moreover, possible linkage of smallholders' commercialization to the export market could enhance foreign currency earnings and improve the balance of payments [14].

\subsection{Enhancement Methods of Smallholders Agricultural Commercialization}

\subsubsection{Agricultural Research}

Research, extension and farmers are the three main pillars of agricultural sector and their effectiveness largely depends on strong linkage among each other and from this farmers' can get improved agricultural technologies, information and support timely [25]. Availability of several improved agricultural technologies generated by agricultural research in Ethiopia over the last four decades improves the agricultural production and productivity. The Ethiopian Institute of Agricultural Research (EIAR) has in recent years introduced agricultural research for development, which is based on the innovation systems approach that involved partnerships with several actors including universities, farmers along the value chain [26]. Using improved crop varieties improves the productivity and quality of output and commercialization of smallholders. The increased in productivity brings additional output over and above home consumption. As a result, higher proportion of the output would be supplied to market [27]. 


\subsubsection{Agricultural Technology Adoption}

Adoption of improved agricultural technologies improves the level of market integration of smallholder farmers. The marketed surplus was overwhelmingly explained by adoption of improved varieties and adoption of improved technologies results in an increase in marketed surpluses [20]. Access to improved seed improves the productivity and quality of output, the increase in productivity brings additional output over and above home consumption. As a result, higher proportion of the output would be supplied to the market [27].

\subsubsection{Improving Extension Service}

Extension agent was used as formal source of production and market information. Extension agents are the conduit for the transfer of technology developed by research centers which is expected to impact positively the output of farmers. Agricultural extension service widens farmers' skills and knowledge, link farmers with improved agricultural technologies and market. In addition, access to production and market information from sources such as television, radio, newspaper, relatives and neighbors are expected to have a positive impact on the degree of commercialization [28].

\subsubsection{Infrastructural Development}

Another area that lays the promise to increase smallholders' commercialization was improvement of infrastructure and institutions. Ethiopia is in the midst of a sustained growth that is becoming increasingly broad-based, major improvements in educational attainment, improved health, and infrastructure capacity in terms of access to all weather road, power, and telecommunications. The development of such infrastructure would help to change the traditional thinking of selling the products on farm and losing much of the products to perishability. Ethiopian government has been investing hugely under GTP-I on rural road construction and during the GTP-II (2016-20) plan set to connect all districts with all-weather roads. Government embarked on a universal rural road access program (URRAP) that sets out to connect all peasant associations by roads of a standard that provides all-weather, year-round access, meets the needs of the rural communities [19].

\subsubsection{Farmers Organization and Collective action}

Farmers' organization was a key contributing factor for successful agricultural commercialization. This is because farmer organizations or collective action works to overcome many hindrances that prevent individual farmers from participating in marketing. A function that farmers' organization provide for smallholders include provision of technical knowledge and market information, access to inputs, improve access to extension services and credit facilities. Successful farmers organization are able to improve social capital, establish a reliable input market through contract arrangements by providing negotiation services and expertise and innovation of new ideas [17].

\subsubsection{Collective Marketing Through Cooperative}

To take advantage of economies of scale, these small and more homogenous groups can build a cooperative, thus acting as a larger group made up of distinct entities. The formation and efficient functioning of smallholder farmers' marketing groups roughly depend on the interaction across three broad factors: 1) the characteristics of the agricultural products and rural markets; 2) the characteristics of the farmers themselves; and 3) the institutional arrangements. Collective marketing in bulk, directly through a producer cooperative or indirectly through collaboration with a marketing service provider was a necessary condition for smallholder producers to overcome the double challenge of high transaction costs and low market power, and essential to commercialize smallholders [23]. Additionally, direct access of farmers to market alleviates the potential exploitation of smallholders by middlemen and other players along the agricultural value chain.

\subsubsection{Improving Access to Finance}

The availability of finance in the form of increased non-farm income, savings and credit are the key factor determining the level of success of market-oriented production and market participation. Credit plays an important role in solving cash constraints needed in production to purchase inputs such as fertilizer, improved seed, crop protection chemicals that used to enhance the production and productivity which in turn has a positive effect on marketable surplus [29]. Hence, combined aspects of credit with input and output marketing had great success in increasing not only outcomes such as incomes and market participation but also farm productivity. At the farm level smallholders credit utilization promotes the uptake of new technologies; and when channeled towards smallholder traders, it leads to thriving rural economies in which surplus production is absorbed [17].

\subsubsection{Development of Irrigation Scheme}

Development of small-scale irrigation scheme encourages smallholders' commercialization. Ethiopian government has made irrigation scheme development as one of its priority agenda and makes many farmers across the country to sustainably produce outputs [30]. Studies estimated that total irrigable land potential in Ethiopia is 5.3 million hectares assuming use of existing technologies and 1.6 million hectares through rain water harvesting and ground water [19]. Under GTP-II (2016-20) the government has set up a plan to construct several mega and medium scale irrigation schemes across different regional states.

\section{Conclusion and Recommendation}

The agricultural sector is a mainstay of the Ethiopian economy. In Ethiopia $95 \%$ of the total area is cultivated by smallholder farmers and contribute $90 \%$ of the total agricultural output. The aim of this review paper is to provide the overview of the processes, determinants, impacts and enhancement methods of smallholder farmers' commercialization in Ethiopia. Smallholders' commercialization has received a greater attention as part of 
the agricultural transformation process and as a consequence of enhancing smallholders' income and economic growth by the government. The concept of smallholders' commercialization goes beyond the marketing of surplus staple products. It comprises households input use decisions, participation in input and output markets, degree of specialization in production and dependence on markets for income and consumption.

Measuring the level of smallholder commercialization are important to make comparisons of households according to their degree of commercialization, it also helps to gauge to what extent a given farm household is commercialized in its overall production, marketing and consumption decisions, and to analyze the determinants of commercialization. As the lessons learned from different literatures social, cultural, institutional and economic factors influence the level of smallholders' commercialization. Household demographic characteristics such as family size, education level, sex of house hold head affect success of smallholders' commercialization. Additionally, household resource endowments, lack of access to infrastructure and agricultural support system on crop production and marketing, climate change, lack of credit and market problem affects smallholders' commercialization.

Significance of smallholders' commercialization on smallholder welfare includes income, employment, consumption, health, and nutrition is high. It enhances the level of household consumption and nutritional status. In this regard, to enhance smallholder's commercialization conducting agricultural research (generating improved high yielding, disease and insect pest resistant varieties are required) and also adoption of these newly released technologies with full production packages are necessary. Agricultural research is important to develop agro-ecology based improved technologies that have the capacity of increasing productivity and profitability through the generation, assessment, refinement, transfer of appropriate technologies. Development agents at rural peasant association (PA) will have to be properly advice farmers about new agricultural technology, soil and water conservation practice and on post-harvest management practically through demonstration at farmers training center (FTC).

Farmers' cooperative and farmers' organization are required to enable smallholder farmers collectively accessing agricultural inputs, credit, information and marketing of their produce. Development and appropriate use of irrigation water to produce year-round are important for production and continuously to supply output to meet market demand and to enhance the livelihood of smallholders. The gaps in the literature particularly in comprehensively conceptualizing the level of commercialization at a household level and in modeling and estimating the determinants and impacts of commercialization should have to be improved further. The use of panel data in commercialization studies than cross-sectional data sets is better to reveal the dynamics of commercialization. In general, based on the review rigorous efforts of all stakeholders, including Governments, research institutions, universities, farmers, NGOs, and development practitioners are needed to eliminate the existing bottlenecks on productivity of smallholder farmers.

\section{References}

[1] MoARD (Ministry of Agriculture and Rural Development). 2010. Ethiopia's Agricultural and Sector Policy and Investment Framework (PIF): 2010-2020, Addis Ababa, Ethiopia.

[2] MoFED (Ministry of Finance and Economic Development). 2015. Growth and Transformational Plan (GTP 2015-2020). Addis Ababa. Ethiopia.

[3] Olwande, J., Smale, M., Mathenge, M. K., Place, F. and Mithofer, D. 2015. Agricultural marketing by smallholders in Kenya: A comparison of maize, kale and dairy. Food Policy 52: 22-32.

[4] Gebremedhin, B. and Jaleta, M. 2010. Commercialization of smallholders: Does market orientation translate into market participation? Improving Productivity and Market Success (IPMS) of Ethiopian farmers project Working Paper 22. Nairobi, Kenya.

[5] Barret, C. B. 2008. Smallholder Market Participation: Concepts and Evidence from Eastern and Southern Africa. Journal of Food Policy, 34, 299-317.

[6] Pingali, L. P and Rosegrant, M. W. 1995. Agricultural commercialization and diversification: Process and policies. Food Policy 20 (3): 171-185.

[7] Romer P. 1994. New goods, old theory and the welfare cost of trade restrictions. Journal of Development Economics 43 (1): $5-38$.

[8] Salami, A., Abdul, K. B and Zuzuna, B. 2010. Smallholder Agriculture in East Africa: Trends, Constraints and Opportunities, Working Papers Series No. 105 Africa Development Bank, Tunis, Tunisia.

[9] Dixon, J., Taniguchi, K. and Wattenbach, H. 2003. Approaches to assessing the impact of globalization on African smallholders: Household and village economy modeling. Proceedings of a Working Session on Globalization and the African Smallholder Study. Food and Agriculture Organization (FAO) and the World Bank, Rome, Italy.

[10] Muller, C. 2014. A test of separability of consumption and production decisions of farm households in Ethiopia. Journal of Poverty Alleviation and International Development 5 (1): $1-18$.

[11] Diao, X., Alemayehu Seyoum, Yu, B., and Pratt, A. N. 2010. Economic Importance of Agriculture for Sustainable Development and Poverty reduction: the case study of Ethiopia. OECD project report on Global report on Agriculture, policies for Agricultural development, poverty Reduction and Food Security OECD Headquarters, Paris. 
[12] Gebre-ab N. 2006. Commercialization of smallholder agriculture in Ethiopia. Ethiopian Development Research Institute, Notes and Papers Series No. 3. Addis Ababa, Ethiopia.

[13] CSA (Central Statistical Agency). 2016. Agricultural Sample Survey 2015/2016 (2008 E. C): Report on area and production of major crops in Ethiopia. Addis Ababa.

[14] Moti Jaleta, Berhanu Gebremedhin and Hoekstra D. 2009. Smallholder commercialization: Processes, determinants and impact. Discussion Paper No. 18. Improving Productivity and Market Success (IPMS) of Ethiopian Farmers Project, ILRI (International Livestock Research Institute), Nairobi, Kenya. $55 \mathrm{pp}$.

[15] Pingali P, Khwaja Y and Meijer M. 2005. Commercializing small farmers: Reducing transaction costs. FAO/ESA Working Paper No. 05-08. FAO (Food and Agriculture Organization of the United Nations), Rome, Italy.

[16] Von Braun, J., Bouis, H. and Kennedy, E. 1994. Conceptual Framework, In: Agricultural Commercialization, Economic Development and Nutrition, Chapter 2, the Johns Hopkins University Press, London.

[17] Johann Kirsten, Mariam Mapila, Julius Okello and Sourovi De. 2012. Managing Agricultural Commercialization for Inclusive Growth in Sub-Saharan Africa. The Global Development Network (GDN, New Delhi.

[18] Efa Gobena, Degye Goshu, Tinsae Demisie and Tadesse Kenea. 2016. Determinants of market participation and intensity of marketed surplus of teff producers in Bacho and Dawo districts of Oromia State, Ethiopia. Journal of Agricultural Economics and Development Vol. 5 (2), pp. 020-032.

[19] Boka Gutu T. 2017. Climate Change Challenges, Smallholders' Commercialization, and Progress out of Poverty in Ethiopia, Working Paper Series $N^{\circ} 253$, African Development Bank, Abidjan, Cote divoire.

[20] Solomon Asfaw, Bekele Shiferaw and Franklin Simtowe. 2010. Does Technology Adoption Promote Commercialization? Evidence from Chickpea Technologies in Ethiopia International Crops Research Institute for the Semi-Arid Tropics, Nairobi, Kenya.

[21] Gebreslassie Hailu, Kebede Manjure and Kiros Meles Aymut. 2015. Crop Commercialization and smallholder farmers' livelihood in Tigray region, Ethiopia.
[22] Zhou, S., Minde, I. J. and Mtigwe, B. 2013. "Smallholder agricultural commercialization for income growth and poverty alleviation in southern Africa: A review", African Journal of Agricultural Research. Vol. 8 (22), pp. 2599-2608.

[23] Andrea Woolverton and David Neven. 2014. Understanding smallholder farmer attitudes to commercialization -The case of maize in Kenya. Rome.

[24] Paul J. Strasberg, T. S. Jayne, Takashi Yamano, James Nyoro, Daniel Karanja, and John Strauss. 1999. Effects of Agricultural Commercialization on Food Crop input use and Productivity in Kenya. Working Paper No. 71 Michigan State University.

[25] Yenesew Sewnet, Edo Elemo and Dereje Derso. 2016. A review of Agricultural Research, Extension and Farmers linkage in Ethiopia. Agriculture and Biology journal of North America. ISSN Print: 2151-7517, ISSN Online: 2151-7525.

[26] Tsedeke Abate, Bekele Shiferaw, Setegn Gebeyehu, Berhanu Amsalu, Kassaye Negash, Kebebew Assefa, Million Eshete, Sherif Aliye and Jürgen Hagmann. 2011. A systems and partnership approach to agricultural research for development Lessons from Ethiopia. Outlook on agriculture. Vol 40, No 3, 2011, pp 213-220.

[27] Kumilachew Alamerie. 2016. Commercialization Behavior of Smallholder Potato Producers the case of Kombolcha Woreda, Eastern part of Ethiopia. Economics of Agriculture. UDC 633.49: 631.1.017.3: 330.13 (63)

[28] Edward Martey. 2014. Market Information and Extent of Agricultural Commercialization: Empirical Evidence from Smallholder Farmers in Effutu Municipality of Ghana American Journal of Experimental Agriculture 4 (12): 1680-1696.

[29] Tadele Mamo, Wudineh Getahun, Agajie Tesfaye, Ali Chebil, Tesfaye Solomon, Aden Aw-Hassan, Tolessa Debele and Solomon Assefa. 2017. Analysis of wheat commercialization in Ethiopia: The case of SARD-SC wheat project innovation platform sites. African Journal of Agricultural Research. Vol. 12 (10), pp. 841-849.

[30] Yodit Balcha (2013). 'Prospects of Transforming Subsistence Agriculture into Sustainable Livelihoods: A case-study of the Ribb sub-Catchment, Ethiopia'. Uppsala University, Sweden. 